\title{
An Exposure and Insight Factors to Student Happiness at Private Universities in Vietnam
}

\author{
Chau Kim Phuong, Phan Vo Minh Thang \\ Faculty of Economics and Business, Hoa Sen University, HCMC, Vietnam
}

*Corresponding Author: Chau Kim Phuong, Faculty of Economics and Business, Hoa Sen University, HCMC, Vietnam

\begin{abstract}
:
Purpose -This study aims to explore the potential indicators and their impact level to student happiness at private universities in Vietnam. The student happiness level is compared among various target groups.

Design/methodology/approach - Key factors were identified based on the literature review of recent researches at first. A pilot test was conducted by interviewing some experts and sending out the online survey to students with the purpose of finalizing the questionnaire from target participants. The study involved 793 students from three popular private universities in Vietnam including Hoa Sen, Van Lang and Hutech. Descriptive statistics, exploratory factor analysis, multiple linear regressions and analysis of variance were applied to explore the factors and compare the happiness differences from target groups of students.
\end{abstract}

Findings - The research results have revealed that student happiness is affected by four factors: (1) Satisfaction with university life; (2) Satisfaction with facilities; (3) Perceived value and (4) Learning experiences. Perceived value is the most powerful influence compared to the other three. More interestingly, the findings of the study have also confirmed that there are no significant differences in the level of student happiness regardless of gender, universities and the year of study.

Practical implications -This study is expected to shed light on the implementation of extra curriculums activities for students in the learning process rather than focus on the infrastructure investment.

Originality/value -The paper shows that exploring these factors and comparing the differences among multiple research groups could present a more accurate understanding for the education managers and stakeholders, also contribute to the advantage of the admission strategies for private universities.

Keywords: Student happiness, private universities, happiness principle, higher education

\section{INTRODUCTION}

Happiness is becoming an emerging strategic vision from organizations to nations. As human beings just living once, people always expect to be happy in life. Firms can win more customers if they provide good services, make customers happy and retain them with pleasures and cares. There are also many scientific studies on human happiness indicators. In the environment of tertiary education, the concept of happiness is very concerned, especially for students. The scientific basis of the method is based on the research on Net Promoter Score by Fred Reichheld, published in Harvard 2002. When students are happy, they not only feel more satisfied with their life and their experience, but also feel more positive emotions than negative ones (Garcia, 1984). In addition, students with a higher level of happiness, they can achieve better academic achievement (Lyubomirskyet al., 2005). Arecent research about the factors affecting students'choice of university has shown that when deciding to choose a university today, students are interested in the following aspects: facilities and services, curriculum, tuition, information about the school, opinions of family and friends, etc. (Mai and Anthony, 2015). So, the enrollment to the universities is becoming more and more competitive, especially in the private ones. Similarly, customers are always the back bone in every organization. Most of the references mentioned in this paper are all based on Chan's et al theory (2005). In addition, this study has designed a questionnaire to measure the student happiness based on the one by the group of authors including Hills and Argyle of Oxford University, UK in 2001, which has been widely referred in many later studies. 
In Vietnam, private universities are operated similarly to the enterprise model because they are invested, built and financially autonomous by individuals or organizations (LuatVietNam, 2018). In particular, students are the customers in tertiary level (Sander et al., 2000; Gremler and McCollough, 2002; Kotze and Plessis, 2003; Chen, 2011), their happiness has a direct impact on universities'revenue and profit (Abdelmotelebet al., 2017). Therefore, factors affecting student happiness are the top concern at the private universities. With the given arguments as above, it would be the ideal conditions for this research. Within the scope of this study, the survey data was collected from three representative private universities in Ho Chi Minh City, namely: Hoa Sen University, Ho Chi Minh City University of Technology (Hutech) and Van Lang University. In which Hoa Sen was the first ranked university out of top 10 happiest ones in 2018 (Edu2Review, 2018). Van Lang and Hutech were not ranked, but were popular to high school students in the past three years. Economics students are the majority in this study.In addition, almost famous private universities are located in $\mathrm{Ho}$ Chi Minh City (MOET, 2019). This selection helps research results be more objective and accurate. Perthe studies about the student happiness: in Australia (Chan et al., 2005); in Finland (Mangeloja and Hirvonen, 2007) and in the UK (Aftab and Paul, 2015), the author has madethe following hypotheses: (1) Satisfaction with university life has positively affected the student happiness; (2) Student motivation has a positive impact on the student happiness at the university; (3) Student experience is a positive influence on the student happiness created by tertiary level.

The main objective of this study is to find out the factors that affect the student happiness at theprivate universities in Ho Chi Minh City. There are three specific objectives as follows: (a) to discover factors affecting the student happiness at private universities in Ho Chi Minh City; (b) to assess the impact of these factors on the student happiness; (c) to compare the differences in happiness levels among the target studied groups (gender, year of study, major and institutions). Thereby, univerities can use the result to better understand their students, create a better learning environment that meets the students'expectations and aspirations. The marketing strategists use this result to grow a specific competition plan in the annual enrollment strategy. Research also helps to provide new facts and findings for a range of issues related to university life, including: student experiences, extracurricular activities, academic results, etc. in influencing the level of student happiness. It helps students better organize and rearrange their personal stuff to achieve a better life. In addition, the topic is also a good reference for further studies on student happiness.

The next section gives a brief overview of public and private university system in Vietnam, followed by a literature review of the recent research on student happiness in the world. The research methodology goes after that, together with the research model. The key findings from the data analysis and discussion are then discussed, and finally are conclusions and recommendations.

\section{Public university \& Private university in Vietnam}

According to the Higher Education Law amended in 2018 (34/2018/QH14), article 7.2 classifies Vietnamese educational institutions into two types:

Public university: a state-owned educational institution run by the Ministry of Education and Training (MOET).The State invests in infrastructure, allocates the funding for their regular spending tasks and also manages resources and budgetof the university.

Private university: an organization that is invested and operated by an individual or an institution, under management of MOET (Vienamese EducationLaw, 2018). Based on the needs of socialeconomic development and training effectiveness of each university, the State may consider supporting a part of the funding. The establishment of the University is decided by the Prime Minister based on the proposal of the MOET and the MOET'soperating license.

Per the latest university education statistics intake 2017 - 2018 from MOET (2019), Vietnam had a total of 235 institutions with 170 public universities and 65 private universities.Particularly in Ho Chi Minh city, there were 46 universities with a total of 12 private institutions and 34 public ones (Uyen, 2018).

\section{LITERATURE REVIEW}

This section aims to clarify some issues related to the research topic such as student happiness in higher educational environment, factors affecting student happiness in previous theory, including: (1) Satisfaction with University's life; (2) Learning motivations and (3) Student experiences. 


\section{Student happiness}

There are many studies both qualitative and quantitative to measure the level of student happiness. In the general literature, the study of Hills and Argyle (2001) is commonly used in many countries around the world as a standard scale to measure the psychological health of people, especially on students.

The Oxford's happiness questionnaire (OHQ) is essentially a toolkit that is inherited from an earlier Oxford-built questionnaire of happiness (OHI). OHI consists of 29 elements, each with four different options. OHI was built in 1989 by the authors Argyle, Martin, and Crossland of Oxford University, UK. This questionnaire has been used and verified in many countries such as Spain, USA, Australia, Canada, Israel and Taiwan. The OHQ questionnaire has also included items similarly to those of OHI, but each item is presented as a statement and the surveyed person will give a score on the Likert scale of six levels ranging from 1 to 6 ( 1 is completely disagree and 6 is strongly agree). Respondents will score over 29 statements depending on the level of agreement from 1 to 6 . The higher score of 29 sentences indicates the higher level of happiness. A total of 172 participants are qualified in this study, including Oxford University students with their friends and relatives, between the ages of 13 and 68. The revised toolkit is easy to manage and has been followed by many authors in Australia (Chan et al., 2005), Finland (Mangeloja and Hirvonen, 2007) and India (Debatree, 2018).

\section{Satisfaction with University's life}

One of the foundational research on the topic "Happiness in University Education" was conducted on the students of Western Australia University from Chan et al. (2005). Data for this study was collected through a survey of 749 economics students, which included 495 first-year students, 174 second-year students, 66 third-year students and 14 forth-year students. The questionnaire is designed to collect a lot of information and is divided into four sections. The first section includes demographic details such as age, gender, the course the studentsare taking, year of study, etc. The following sections include questions regarding their experience at school, their life at the university and their postgraduate plans. The five-level scale inherited from previous study on health and satisfaction (Bradburn, 1969; Easterlin, 1974; Di Tellaet al., 2001) was used to measure the level of satisfaction from 1 (strongly disagree) to 5 (strongly agree). The survey results exposed that one of the important factors affecting student happiness was the satisfaction with university life, which the author measured on 5 aspects: school work, time management, relationships are formed in the university, the learning environment and the university's reputation. Accordingly, the more students are satisfied with university's life, the higher level of happiness they belong to.

Inheriting the research of Chan et al. (2005), a group of authors Mangeloja and Hirvonen (2007) conducted a research entitled "What Makes University Students Happy?" on Economics students at the second largest university in Finland, Jyväskylä (with 16,000 full-time students). A total of 246 qualified questionnaires analyzed werecompared to survey data from Australian students by Chan et al. (2005) and gave the similar results. The most important influences on student satisfaction in university life are social relationships, resources and educational environment and satisfaction with school work. The university's time management and reputation are not of interest to Finnish students. In addition, a newly factor extracurricular activity has been discovered:That students participate in too many extra-curriculars and spend too much time on these activities would reduce their happiness level.

\section{Learning motivations}

Student motivation is considered as one of the interesting factors that positively affects student wellbeing in the study of Aftab and Paul (2015). The study was conducted on 308 students from two universities in the north of England. The author argued that motivation was a sign of happiness and influenced students' achievement and their future plans. Students who achieve higher happiness would often make better decisions in the future. However, to measure the learning motivation, the author only used total time student had spent for the self-study as a unique indicator.

On the other hand, when studying the relationship between student motivation and academic performance, a group of authors Afzal and Ali (2010) distinguished student motivation into two categories: intrinsic motivation from inside student and extrinsic motivation from the impact of the environment. In particular, extrinsic motivation was divided into four groups: (1) Refuse alternatives, 
for example, students choose to go to college because they may want to avoid mandatory military duties, do not like to work or don't know what else to do; (2) Career opportunities and qualifications; (3) Love to gain many social relationships; (4) Pressure from family, friends and society. The study was conducted on 342 students from three different universities in Pakistan. Within the scope of this study, the author has been interested in extrinsic motivation because there might be some factors that university can influence to enhance their customer's motivaton. Therefore, we inherited Afzal and Ali (2010) concepts and methods to measure learning motivation of Vietnamese students.

\section{Student experiences}

Also in a study of Aftab and Paul (2015), the relationship between student happiness and experience at school was confirmed. There were 10 elements of the experience that students were interested in, ranking in order of priority from highest to lowest as below:

(1) Having good friends at school;

(2) University is a worthwhile investment;

(3) Feel safe and secure at school;

(4) Recognize the benefits of higher education;

(5) Complete the assignment on time;

(6) Having a good social life;

(7) Having good relationship with classmates;

(8) Lecturers send learning materials on the online system;

(9) Lecturers are friendly;

(10) Regularly attend university's workshops.

Other studies of student happiness in Vietnam and around the world most likely focused on the general human happiness (Ngan, 2017; Ha, 2017) or tried to connect the relationship of a single factor on student happiness (Chan et al., 2005; Mangeloja and Hirvonen, 2007; Aftab andPaul, 2015). This factor may come from inner or outer influences. The scope of those researches are on students at all level, regardless of years of study and whether they are studying in public or private universities. In the context of Vietnam, understanding student happiness and the factors affecting student happiness are especially important foreducational managers and investors and even the students themselves. Therefore, this study is mainly focusing on indicators of a private university to influence the student happiness.

\section{RESEARCH METHODOLOGY}

\section{Participants}

The study was conducted at three private universities at Ho Chi Minh City in Vietnam with the total number of 793 students from 16 classes of second, third, and fourth academic years of nine faculties including Korean Studies, Japanese Studies, Business Administration, Tourism Management, Finance and Banking, Information Technology, Industry of Food, Arts Design, Electronic Engineering participated in the study.

\section{Research instruments}

The study employed just one major instrument for collecting both quantitative and qualitative data. The questionnaire consists of two parts; part one is about the demographic information of the participants and part two is about 31 variables highlighting the factors to influence student happiness including satisfaction with university's life; student experiences; learning motivation and measuring student happiness level. All items of the questionnaires were specially designed according to 5-point Likert scale ranging from 1 (Strongly Disagree); 2 (Disagree); 3 (Neutral); 4 (Agree); 5 (Strongly Agree); and for the students, the questionnaire items were translated into Vietnamese. We also collected the questionnaires through a convenience sampling strategy (Hair et al., 2011).

\section{Data collection and analysis procedures}

The data collection for this study was carried out from August to November 2019. The questionnaires were dispatched and gathered in the classrooms. In order to approach the targeted participants, an 
initial meeting with lecturers to introduce the purposes of the research was conducted in advance. A total of 816 questionnaire copies were administered to the students of nine faculties, 793 copies were correctly and validly completed (97.1\%).

Regarding data analysis procedures, in order to analyze quantitative data collected from the questionnaires, descriptive statistics was employed through the use of SPSS version 20. Percentages, mean scores and standard deviation were then calculated.

The questionnaire was pilot tested with 60 undergraduate students from different economics majors to ensure the validity of the questions and make necessary adjustments. For quantitative research, cronbach's alpha of scalesis. 60 and correlationis. 30, indicating that the scales has acceptable internal consistency. Exploratory factor analysis (EFA) and multiple linear regression (MLR) are conducted to verify the research model. In order to measure the statistical significance of differences between the target groups, simple t-test is used for gender and one-way ANOVA test is used for school, major and year of study.

\section{Research Model}

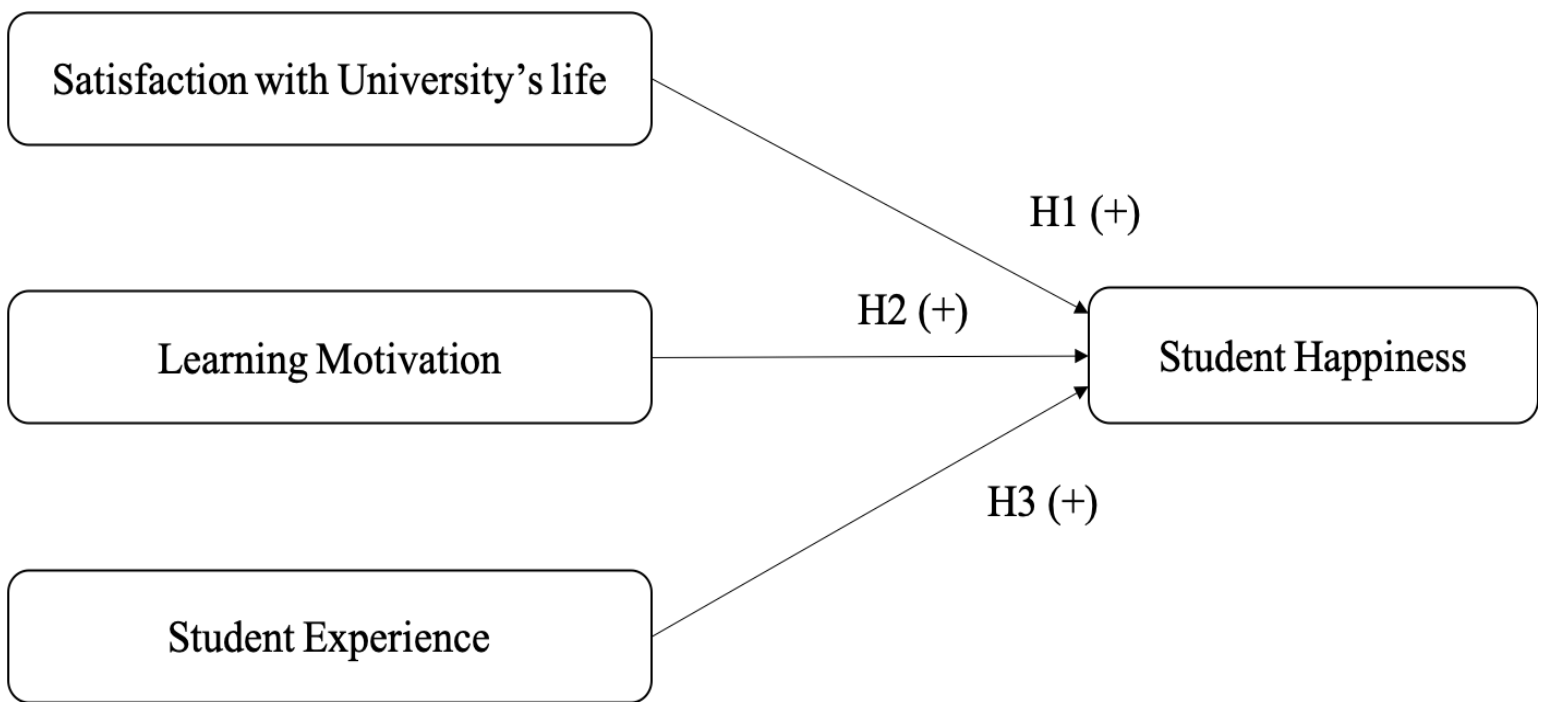

Figure1. Factors Affecting Student Happiness at Private Universities

From the above arguments, the authors hypothesize all three factors positively affecting student happiness as follow:

H1. Satifaction with University's life is positively associated with student happiness.

H2. Learning Motivation of student is positively associated with student happiness.

H3. Student Experiences at school are positively associated with student happiness.

\section{RESUltS AND DiSCUSSION}

A sample of 816 survey responses were collected in October, 2019, including 673 direct surveys $(82.2 \%)$ and 141 online surveys (17.8\%). After eliminating 23 null values due to the lack of information and options, the valid results were used for analysis including 793 samples from three universities: Hoa Sen (319), Hutech (263) and Van Lang (211). Table I below summarizesthe respondent statistics by gender, school, major and year of study.

Table I.

Respondent Statistics

\begin{tabular}{|l|l|l|l|}
\hline \multicolumn{2}{|l|}{ Grouping } & Responses & Ratio (\%) \\
\hline \multirow{3}{*}{ Gender } & Male & 263 & 33.2 \\
\cline { 2 - 4 } & Female & 530 & 66.8 \\
\cline { 2 - 4 } & Total & $\mathbf{7 9 3}$ & $\mathbf{1 0 0}$ \\
\hline \multirow{4}{*}{ University } & Hoa Sen & 319 & 40.2 \\
\cline { 2 - 4 } & Hutech & 263 & 33.2 \\
\cline { 2 - 4 } & Van Lang & 211 & 26.6 \\
\cline { 2 - 4 } & Total & $\mathbf{7 9 3}$ & $\mathbf{1 0 0}$ \\
\hline
\end{tabular}


An Exposure and Insight Factors to Student Happiness at Private Universities in Vietnam

\begin{tabular}{|l|l|l|l|}
\hline \multirow{5}{*}{ Major } & Accounting - Finance & 93 & 11.7 \\
\cline { 2 - 4 } & International Business & 72 & 9.1 \\
\cline { 2 - 4 } & Economic Law & 62 & 7.8 \\
\cline { 2 - 4 } & Marketing & 32 & 4 \\
\cline { 2 - 4 } Year of Study & Business Administration & 275 & 34.7 \\
\cline { 2 - 4 } & Human Resource Management & 9 & 1.1 \\
\cline { 2 - 4 } & Others & 250 & 31.5 \\
\cline { 2 - 4 } & Total & $\mathbf{7 9 3}$ & $\mathbf{1 0 0}$ \\
\hline & $2^{\text {nd }}$ Year & 362 & 22.2 \\
\cline { 2 - 4 } & $3^{\text {rd }}$ Year & 255 & 45.6 \\
\cline { 2 - 4 } & $4^{\text {th }}$ Year & $\mathbf{7 9 3}$ & 32.2 \\
\cline { 2 - 4 } & Total & $\mathbf{1 0 0}$ \\
\hline
\end{tabular}

The participants completing the questionnaires contributed $66.8 \%$ female and $33.2 \%$ male. Economics students arethe majority with $68.5 \%$ compared to the students from other majors (including Management Information System, Media Technology Administration, Public Relation, Information Technology, Oriental Studies, Mechanical Engineering, English Language, Graphic Design and Applied Mathematics) occupying 31.5\%. Students from third year comprise the most responses with $45.6 \%$, following the forth year students with $32.2 \%$ and finally second year students with $22.2 \%$.

The result of Cronbach's alpha and EFA test had excluded four items of learning motivation $(C R A=$ $0.355<0.6)$ and two items of student experience in which variable SE06 has a total correlation coefficient is $0.278<0.3$ and variable SE0 1 has factor loading $<0.3$ in which these 6 variables did not meet the minimum reliability requirement(Hair et al., 2011). In this research, learning motivation did not affect student happiness at school. The hypothesis $\mathrm{H} 2$ has been removed from research model. While the previous study in England by Aftab and Paul (2015) discovered the motivation of learning and student experience resulting in a positive impact on happiness. The difference in these studies results can be explained by the differences in culture, time of survey and educational philosophy of each nation. For Vietnamese students, motivation might be an intrinsic manner from individual rather than external activities that the institution can impact to.

\section{Factors affecting student happiness}

In order to examine the underlying structure of numerous factors affecting the student happiness, an exploratory factor analysis was conducted under the condition of significance level in Bartlett's Test sig. $(p=0.000<0.05)$ and Kaiser-Meyer-Olkin coefficient measure of sampling adequacy $(K M O=$ $0.905>0.5)$ indicatingthat the variables were correlated with each other in the factor. Thus, the initial conditions were met to conduct a factor analysis (Hair et al., 2011). Varimax rotation and eigenvalue extraction criteria method was used and a total of 25 variables were grouped based on five extracted factors. All five factors having eigen value values $>1$ are satisfactory to be retained in the model. The total variance extracted is $53.38 \%>50 \%$, indicating that the EFA model is suitable and could explain 53.38 percent of total variation in the data set. In addition, the 25 observed variables all have factor loading $>0.3$, which is sufficient for the variables to be retained in the model for sample sizes $>350$ (Hair et al., 2011).Table II below represented the five factors extracted after testing EFA. The details of Cronbach's alpha and EFA analysis are summarized in the Appendix.

Table II. New Factors

\begin{tabular}{|c|c|c|}
\hline Variables & Statements & New factors \\
\hline SA01 & I have sufficient recreational and entertainment time outside the home. & \multirow{5}{*}{$\begin{array}{l}\text { Satisfaction with } \\
\text { University's Life } \\
\text { (SA) }\end{array}$} \\
\hline SA02 & I can balance work and university activities well. & \\
\hline SA03 & I can meet deadlines or goals in my university work. & \\
\hline SA04 & I am given the chance to do work that really interests me. & \\
\hline SA05 & I am happy with the marks I have achieved so far in university. & \\
\hline SA07 & I am happy with my work environment. & \multirow{3}{*}{$\begin{array}{lr}\text { Satisfaction with } \\
\text { Resources and } \\
\text { University } \\
\text { Environment(SA2) }\end{array}$} \\
\hline SA08 & The conditions of buildings and the sports facilities are good. & \\
\hline SA09 & I feel safe and secure. & \\
\hline SE02 & Education is a worthwhile investment. & \multirow{3}{*}{$\begin{array}{l}\text { Perceived Value } \\
\text { (SE2) }\end{array}$} \\
\hline SE03 & I am aware of benefits of Higher Education. & \\
\hline $\mathrm{SH} 02$ & I feel that life is very rewarding. & \\
\hline
\end{tabular}


An Exposure and Insight Factors to Student Happiness at Private Universities in Vietnam

\begin{tabular}{|c|c|c|}
\hline SA06 & I enjoy the modules on my course. & \multirow{3}{*}{$\begin{array}{l}\text { Learning } \\
\text { Experience } \\
\text { (SE) }\end{array}$} \\
\hline SE04 & Tutors post material onUNI online system. & \\
\hline SE05 & Tutors are friendly. & \\
\hline SH01 & I am intensely interested in other people. & \multirow{11}{*}{$\begin{array}{l}\text { Student Happiness } \\
\text { (SH) }\end{array}$} \\
\hline $\mathrm{SH} 03$ & I have very warm feelings towards almost everyone. & \\
\hline $\mathrm{SH} 04$ & I am always committed and involved. & \\
\hline SH05 & I laugh a lot. & \\
\hline SH06 & I am well satisfied about everything in my life. & \\
\hline SH07 & I always have a cheerful effect on others. & \\
\hline SH08 & I can fit in everything I want to. & \\
\hline SH09 & I feel fully mentally alert. & \\
\hline SH10 & I often experience joy and elation. & \\
\hline SH11 & I feel I have a great deal of energy. & \\
\hline SH12 & I usually have a good influence on events. & \\
\hline
\end{tabular}

To meet the initial research objectives, the model of multi-linear regression analysis was applied to determine the importance of each factor affecting the student happiness. The results of $R^{2}=0.366$, Durbin-Watson value $=1,836$ and $\mathrm{p}<0.05$ showed that the linear regression model built was suitable, could be extrapolated and applied to the whole. It also presented that the independent variables impacted 36.6\% the change of the dependent variable ( $\mathrm{SH})$. The research result showed that perceived value (SE) is the most influential factor on student happiness (beta $=0.306$ ). The second factor affecting student happiness is satisfaction with university life (SA) with beta $=0.215$, followed by the learning experience (SE) with beta $=0.156$ and finally is the satisfaction with facilities (SA2) that affect student happiness theleast (beta $=0.12$ ). All four factors have a positive impact on student happiness (see Table III, IV and V).

Table III. Model Summary of testing MLR

\begin{tabular}{|r|c|r|r|r|r|}
\hline Model & $\mathrm{R}$ & $\mathrm{R}$ Square & Adjusted R Square & $\begin{array}{c}\text { Std. Error of the } \\
\text { Estimate }\end{array}$ & Durbin-Watson \\
\hline 1 & $.605^{\mathrm{a}}$ & 0.366 & $\mathbf{0 . 3 6 2}$ & 0.47903 & $\mathbf{1 . 8 3 6}$ \\
\hline
\end{tabular}

Table IV. ANOVA of testing MLR

\begin{tabular}{|l|l|l|l|l|l|l|}
\hline \multicolumn{2}{|l|}{ Model } & $\begin{array}{l}\text { Sum of } \\
\text { Squares }\end{array}$ & df & Mean Square & F & Sig. \\
\hline \multirow{3}{*}{1} & Regression & 104.173 & 4 & 26.043 & 113.494 & $\mathbf{. 0 0 0}^{\mathbf{b}}$ \\
\cline { 2 - 8 } & Residual & 180.821 & 788 & 0.229 & & \\
\cline { 2 - 7 } & Total & 284.994 & 792 & & & \\
\hline
\end{tabular}

Table V. Coefficients of testing MLR

\begin{tabular}{|c|c|c|c|c|c|c|c|c|}
\hline \multirow{2}{*}{\multicolumn{2}{|c|}{ Model }} & \multicolumn{2}{|c|}{$\begin{array}{l}\text { Unstandardized } \\
\text { Coefficients }\end{array}$} & \multirow{3}{*}{$\begin{array}{l}\text { Standardized } \\
\text { Coefficients } \\
\text { Beta } \\
\end{array}$} & \multirow{3}{*}{$\begin{array}{l}\mathrm{t} \\
6.14 \\
\end{array}$} & \multirow{3}{*}{$\begin{array}{l}\text { Sig. } \\
0 \\
\end{array}$} & \multicolumn{2}{|c|}{$\begin{array}{l}\text { Collinearity } \\
\text { Statistics }\end{array}$} \\
\hline & & $\mathrm{B}$ & Std. Error & & & & \multirow[t]{2}{*}{ Tolerance } & \multirow[t]{2}{*}{ VIF } \\
\hline \multirow{5}{*}{1} & (Constant) & 0.791 & 0.129 & & & & & \\
\hline & $\begin{array}{ll}\text { Satisfaction } & \text { with } \\
\text { University's } & \text { Life } \\
\text { (SA) } & \\
\end{array}$ & 0.199 & 0.031 & 0.215 & 6.483 & 0 & 0.735 & 1.361 \\
\hline & $\begin{array}{l}\text { Satisfaction with } \\
\text { Resources and University } \\
\text { Environment } \\
\text { (SA2) }\end{array}$ & 0.092 & 0.026 & 0.12 & 3.569 & 0 & 0.709 & 1.41 \\
\hline & Learning Experience (SE) & 0.137 & 0.03 & 0.156 & 4.559 & 0 & 0.685 & 1.46 \\
\hline & Perceived Value (SE2) & 0.277 & 0.03 & 0.306 & 9.265 & 0 & 0.736 & 1.359 \\
\hline
\end{tabular}




\section{Dependent variable: Students' Hapiness}

Thus, after being verified and analyzed in detail, student happiness is influenced by four factors ranked according to the highest level of influence as follows: (1) Perceived value; (2) Satisfaction with university's life; (3) Learning experience and (4) Satisfaction with Resources and University Environment. Compared to the original hypothesis, only factor of learning motivation did not meet with the statistic analysic. It cannot be concluded yet as a positive impact on the happiness of Vietnamese students in the context of this study. The remaining factors all showed the homogeneity with the results of Chan et at., (2005), Mangeloja and Hirvonen (2007), Aftab and Paul (2015). The result was perfectly suitable on the target groups of students from second year onwards because they spent a period of time studying at school and gained enough experience to feel the happiness. Vietnamese students believe that the more they realize the values of university investment, the more happy they are, as follows:

"Education is a worthwhile investment." (SE02)

"I am aware of benefits of Higher Education." (SE03)

"I feel that life is very rewarding." (SHO2)

The other factors revevant to infrastructure and learning environment such as "I am happy with my work environment." (SA07); "The conditions of buildings and the sports facilities are good." (SA08) and "I feel safe and secure." (SA09) expose the lowest impacts on student happiness.

Differences of student happiness level among genders, year of study, majors and school

In order to explore the differences of happiness level among groups of participants, an independent simple t-test with a significant level of 0.05 was set to verify the differences of respondents' happiness level between genders. The results showed that there was no statistically significant difference in the level of happiness between male and female students (Coefficient of Sig Levene's test $=0.146>0.05$, $t=3.051>0.05$ ). Further to year of study, majors and the surveyed schools, ANOVA was applied to analyse the differences in responses among the target groups. There were no statistically significant differences in the level of happiness among second, third and fourth year students (sig Levene's test = $0.34>0.05$, sig. between groups $=0.984>0.05$ ); and among the surveyed schools (sig Levene's test $=0.144>0.05$, sig. between groups $=0.456>0.05)$. However, among the three private representative institutions in Ho Chi Minh city, Hutech University students have the highest level of happiness $(M=3.54, S D=0.58)$, followed by Van Lang University students $(M=3.5, S D=0.64)$ and finally students of Hoa Sen University $(M=3.49, S D=0.56)$. Interestingly, students of different majors had different levels of happiness $($ sig. $=0.022<0.05)$. In the economics groups, Human Resource Management students are the happiest $(M=3.8, S D=0.72)$, following are students from Economic Law $(M=3.57, S D=0.66)$, Accounting-Finance $(M=3.56, S D=0.55)$, Business Administration $(M=3.54, S D=0.54)$, International Business $(M=3.32, S D=0.62)$, and finally Marketing $(M=3.31, S D=0.74)$. Students from the rest of majors had the happiness level rather higher than the average $(M=3.52, S D=0.62)$ (see Table VI). Overall, the student happiness level at private universities in Ho Chi Minh city is currently high (3.5/5.0).

Table VI. Differences of happiness level among majors

\begin{tabular}{|l|l|r|r|r|}
\hline & Major & Mean & $\mathrm{N}$ & $\%$ of Total N \\
\hline \multirow{5}{*}{ Student happiness } & Human Resource Management & 3.80 & 9 & $1.1 \%$ \\
\cline { 2 - 5 } & Economic Law & 3.57 & 62 & $7.8 \%$ \\
\cline { 2 - 5 } & Accounting-Finance & 3.55 & 93 & $11.7 \%$ \\
\cline { 2 - 5 } & Business Administration & 3.54 & 275 & $34.7 \%$ \\
\cline { 2 - 5 } & International Business & 3.32 & 72 & $9.1 \%$ \\
\cline { 2 - 5 } & Marketing & 3.31 & 32 & $4.0 \%$ \\
\cline { 2 - 5 } & Others & 3.52 & 250 & $31.5 \%$ \\
\cline { 2 - 5 } & Total & 3.51 & 793 & $100.0 \%$ \\
\hline
\end{tabular}

\section{CONCLUSIONS AND RECOMMENDATIONS}

This research has explored the factors that influence the student happiness at private universities. The previous studies suggested three factors that the authors proposed in the orginal research model 
including satisfaction with university life, learning motivation and student experience. In addition, authors also evaluated the differences in happiness level among different target groups by gender, year of study, major and surveyed universities.

This study's findings confirmed the following drivers to student happiness at private universities: (1) Satisfaction with university life; (2) Satisfaction with facilities; (3) Perceived values and (4) Learning experience in which the element of student motivation was removed from the model. The results demonstrated that the motivation of Vietnamese students in this research does not affect their happiness at university. While the previous study in UK by Aftab and Paul (2015) discovered that learning motivation has a positive impact on student well-being beyond experience. This difference can be explained by the large differences in culture, time of the survey and educational philosophy of each country.

Among the four factors positively impacting student happiness, the perceived value has the most significant impact. Students from second year onwards are perfectly the target audience for the research because they have enough time to learn the knowledge at school and experience the happiness. Specifically, for Vietnamese students, the more they experience the perceived value of going to school, the more happy they are.

Per the interesting findings mentioned, educators and top managers have more reasons to consider investing more experiential activities integrated into practical subjects rather than just developing facilities. This helps create more outstanding values and increase the competitiveness among the private universities in Vietnam.

Through the results of data analysis, the research questions have been solved. The initial research goal is met to find out factors that influence the happiness of private university students. Thereby, managers, marketers, administrators and investors can use it to make the appropriate development strategy. One of the strategies is to influence the well-being of students through ways of increasing perceptions, satisfaction of university life, satisfaction of facilities and increasing students' experiences at university.

Like any other researches, this study has limitations due to limited resources as well as sampling conditions. The comprehensiveness of the research is not high enough because the surveyed location is only Ho Chi Minh city. Random sampling on economics students at private universities is applied, which does not have comprehensive coverage for Vietnamese students. Research tools applied are expert interviews and questionnaire surveys. Due to time constraints and resources, in-depth research tools such as group interviews and observations cannot be applied. For further research, the target groups could be expanded to nationwide level in which further measuring of the happiness and indicators could be compared between the public and private universities. More research methodologies should be conducted to better understand student's insight factors. This research has explored the differences of happniess level among different groups, however more deep-dive group analysis might help to reveal how different the identified factors impact the student happiness across groups of participants. In addition, groups can be formulated from freshmen ( ${ }^{\text {st }}$ year students) and others for more insights and elaborations.

\section{REFERENCES}

[1] Abdelmoteleb, A.A.Sh.,Kamarudin, S. andNohuddin, P.N.E. (2017), "Data driven customer experience and the roadmap to deliver happiness", AIMI Journal, pp.236-248.

[2] Aftab, D. and Paul, G. (2015), “Student satisfaction or happiness?", Quality Assurance in Education, 23(1), 5-19. doi:10.1108/qae-10-2013-0044.

[3] Afzal, H. and Ali, I. (2010), "A Study of University Studentss Motivation and Its Relationship with Their Academic Performance”, SSRN Electronic Journal, doi:10.2139/ssrn.2899435.

[4] Argyle, M. (2001), "The Psychology of Happiness", London: Routledge, https://doi.org/10.4324/ 9781315812212.

[5] Bradburn, N.M. (1969), "The Structure of Psychological Well-being", Chicago: Aldine.

[6] Chan, G., Miller, P. and Tcha, M. (2005),"Happiness in university education”, International Review of Economics Education, Vol. 4 No. 1, pp.20-45.

[7] Chen, S. (2011), "A performance matrix for strategies to improve satisfaction among faculty members in higher education”, Quality and Quantity, 45(1), pp.75-89. 
[8] Di Tella, R., MacCulloch, R.J. and Oswald, A.J. (2001), "Preferences over Inflation and Unemployment: Evidence from Surveys of Happiness”, American Economic Review, Vol. 91(1), pp.335-341.

[9] Easterlin, R.A. (1974), "Does Economic Growth Improve the Human Lot? Some EmpiricalEvidence",Nationsand Householdsin Economic Growth: Essays in Honor of Moses Abramovitz, New York and London: Academic Press, pp.89-125.

[10] Garcia, D. (1984), “Adolescents' happiness: The role of the affective temperament model on memory and apprehension of events, subjective well-being, and psychological well- being”,Ph.D. Thesis, University of Gothenburg, Gothenburg, Sweden.

[11] Gremler, D.D. and McCollough, M.A. (2002), "Student satisfaction guarantees: an empirical examination of attitudes, antecedents, and consequences",Journal of Marketing Education, Vol. 24 No. 2, pp.150-260.

[12] Ha, T.T.K. (2017), “Thang do chi so hanh phuc (PWI) - Thu nghiem tren mau sinh vien (Personal wellbeing index scale - Test on Vietnamese students)",Psychological magazine, No.6 (219).

[13] Hair, J.F. , Black, W.C. , Babin, B.J. and Anderson, R.E. (2010), “Multivariate Data Analysis”, Prentice Hall, Upper Saddle River, NJ.

[14]Hills, P. and Argyle, M. (2001), "The Oxford Happiness Questionnaire: A compact scale for the measurement of psychological well-being",Personality and Individual Differences, 33(7), 1073-1082. doi:10.1016/s0191-8869(01)00213-6.

[15] "Khung he thong giao duc quoc dan (The framework of international educational system)", available at: https://thuvienphapluat.vn/van-ban/Giao-duc/Quyet-dinh-1981-QD-TTg-phe-duyet-khung-co-cau-hethong-giao-duc-quoc-dan-328234.aspx.

[16] Kotze, T.G. and Plessis, P.J. (2003), "Students as co-producers of education: a proposed model of student socialization and participation at tertiary institutions", Quality Assurance in Education, Vol. 11 No. 3, pp. 277-288.

[17] Lyubomirsky, S., King, L. and Diener, E. (2005), “The Benefits of Frequent Positive Affect: Does Happiness Lead to Success?”, Psychological Bulletin, 131(6), 803-855. https://doi.org/10.1037/00332909.131.6.803.

[18] Mai, D.T.N. and Anthony, T. (2015),"What factors influence Vietnamese students' choice of university?",International Journal of Educational Management, Vol. 29 Issue: 5, pp.666681,https://doi.org/10.1108/IJEM-08-2014-0110.

[19] Mangeloja, E. and Hirvonen, T. (2007), “What Makes University Students Happy?”,International Review of Economics Education, 6(2), 27-41.doi:10.1016/s1477-3880(15)30105-5.

[20] Ministry of Education and Training (MOET) (2017), "Thong tu 12/2017/TT-BGDĐT (Announcement 12/2017/TT-BGDDT)", available at:http://www.moet.gov.vn/van-ban/vanban/Pages/chi-tiet-vanban.aspx?ItemID=1255 (accessed May, 2017).

[21] Ministry of Education and Training (MOET) (2019), "So lieu thong ke giao duc dai hoc nam 2017 - 2018 (University education statistics, intake 2017 - 2018), ,available at:https://moet.gov.vn/thongke/Pages/thong-ko-giao-duc-dai-hoc.aspx?ItemID=5877(accessed March 13, 2019).

[22] Ngan, D.H. (2017), “Thich ung thang do cam nhan hanh phuc tam ly cua Carol Ryff tren khach the sinh vien (Adapt the Ryff's psychological well-being scale for Vietnamese participants)",Psychological magazine, No. 2 (215).

[23] "Quyet dinh ve viec ban hanh quy che Dai hoc tu thuc (Decision of Private University Regulations)", available at: https://thuvienphapluat.vn/van-ban/Giao-duc/Quyet-dinh-240-TTg-Quy-che-Dai-hoc-tu-thuc38578.aspx.

[24] Sander, P., Stevenson, K., King, M. and Coates, D. (2000), "University students' expectations of teaching”, Studies in Higher Education, Vol. 25 No. 3, pp.309-323.

[25] "Tong quan he thong giao duc nuoc My (The overview of US education system)", available at: http://oxford.edu.vn/tu-van-du-hoc/du-hoc-my/tong-quan-he-thong-giao-duc-nuoc-my-1084.html.

[26] “Top 10 truong Dai hoc hanh phuc nhat nam 2018 (Top 10 happiness universities in Vietnam)", available at:https://edu2review.com/reviews/top-10-truong-dai-hoc-hanh-phuc-nhat-tot-nhat-viet-nam-8245.html (accessed May, 2019).

[27] VietNam Education Law (2018)", available at: https://luatvietnam.vn/giao-duc/luat-giao-duc-dai-hoc-suadoi-nam-2018-169346-d1.html.

\section{APPENDIX}

Table VII. Reliability Statistics

\begin{tabular}{|c|c|c|c|c|}
\hline Items & Code & Cronbach's Alpha & $\begin{array}{l}\text { Corrected Item- } \\
\text { Total Correlation }\end{array}$ & $\begin{array}{l}\text { Cronbach's Alpha if } \\
\text { Item Deleted }\end{array}$ \\
\hline \multirow{2}{*}{$\begin{array}{ll}\text { Satisfaction } & \text { with } \\
\text { University's life } & \end{array}$} & SA01 & \multirow{2}{*}{0.785} & 0.472 & 0.764 \\
\hline & $\mathrm{SA} 02$ & & 0.489 & 0.761 \\
\hline
\end{tabular}




\begin{tabular}{|c|c|c|c|c|}
\hline \multirow[t]{7}{*}{$(\mathrm{SA})$} & SA03 & & 0.501 & 0.76 \\
\hline & SA04 & & 0.49 & 0.761 \\
\hline & SA05 & & 0.409 & 0.772 \\
\hline & SA06 & & 0.433 & 0.769 \\
\hline & SA07 & & 0.529 & 0.756 \\
\hline & SA08 & & 0.466 & 0.765 \\
\hline & SA09 & & 0.44 & 0.769 \\
\hline \multirow{4}{*}{$\begin{array}{l}\text { Learning Motivation } \\
\text { (SM) }\end{array}$} & SM01 & \multirow{4}{*}{0.355} & 0.093 & 0.43 \\
\hline & SM02 & & 0.172 & 0.313 \\
\hline & SM03 & & 0.166 & 0.317 \\
\hline & SM04 & & 0.358 & 0.062 \\
\hline \multirow{6}{*}{$\begin{array}{l}\text { Student Experience } \\
\text { (SE) }\end{array}$} & SE01 & \multirow{6}{*}{0.699} & 0.398 & 0.669 \\
\hline & SE02 & & 0.462 & 0.651 \\
\hline & SE03 & & 0.511 & 0.636 \\
\hline & SE04 & & 0.487 & 0.64 \\
\hline & SE05 & & 0.48 & 0.643 \\
\hline & SE06 & & 0.278 & 0.715 \\
\hline \multirow{12}{*}{$\begin{array}{l}\text { Student Happiness } \\
(\mathrm{SH})\end{array}$} & SH01 & \multirow{12}{*}{0.876} & 0.496 & 0.87 \\
\hline & SH02 & & 0.51 & 0.869 \\
\hline & SH03 & & 0.628 & 0.862 \\
\hline & SH04 & & 0.462 & 0.872 \\
\hline & SH05 & & 0.583 & 0.865 \\
\hline & SH06 & & 0.568 & 0.866 \\
\hline & SH07 & & 0.59 & 0.864 \\
\hline & SH08 & & 0.57 & 0.866 \\
\hline & SH09 & & 0.629 & 0.862 \\
\hline & SH10 & & 0.662 & 0.86 \\
\hline & SH11 & & 0.655 & 0.86 \\
\hline & SH12 & & 0.475 & 0.872 \\
\hline
\end{tabular}

\section{AUTHORS' BIOGRAPHY}

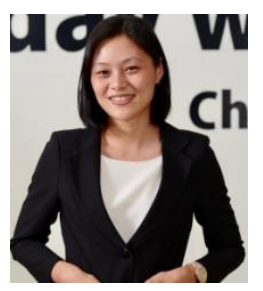

Ms. Chau Kim Phuong, has strong backgrounds in business administration, information technology and linguistic. She had over 8 years experiences working as an executive dean assistant at Faculty of Economics and Business of Hoa Sen University, a top of private university in Vietnam.

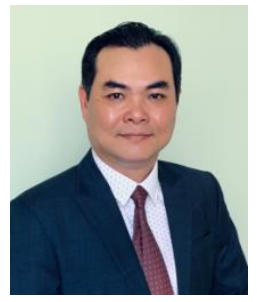

Dr. Phan Vo Minh Thang, the corresponding author, is currently the MBA Program Manager and lecturer at Hoa Sen University in Vietnam. He was the former Director of SSP Academy (a Saigon Software Park's subdivision that provides IT training services) and Lecturer at HCM University of Pedagogies, Nong Lam University. Dr. Phan Vo Minh Thang's researches have been published in the Higher Education, Skills and Work-Based Learning (Scopus indexed), Social Science Research Network (SSRN). He reviewed articles from the Quality Assurance in Education Journal and the Journal of Economic Literature.

Citation: Chau Kim Phuong, Phan Vo Minh Thang, “ An Exposure and Insight Factors to Student Happiness at Private Universities in Vietnam" International Journal of Managerial Studies and Research (IJMSR), vol 8, no. 5, 2020, pp. 21-31. doi: http:// dx.doi.org/10.20431/2349-0349.0805003.

Copyright: (C) 2020 Authors. This is an open-access article distributed under the terms of the Creative Commons Attribution License, which permits unrestricted use, distribution, and reproduction in any medium, provided the original author and source are credited. 